\title{
URBAN TOOLS AND GOOD PRACTICES: REALIZING SUSTAINABLE PUBLIC SPACES
}

\author{
MARICHELA SEPE \\ ISMed National Research Council - DIARC University of Naples Federico II, Italy
}

\begin{abstract}
The research - titled Public Spaces. From Principles to Practice - illustrated in this paper was carried out by the author in the framework of the Urban Maestro New Governance Strategies for Urban Design Horizon 2020 research project and the INU Community Public Space, the latter coordinated by the author. The Urban Maestro Project - coordinated by the UCL and in partnership with UN-Habitat - "looks at the ways European cities are being designed and financed, focusing on innovative ways of generating and implementing urban spatial quality". Among the objective, the project compares experiences in Europe to international practices. Accordingly, the author, as a member of the Advisory and Support Group, shared the good Italian practices in the public space field. The Community Public Space has the objective to collect best practices of public space in Italy, starting from the Charter of Public Space, which was adopted during the second Biennial of Public Space held in Rome in 2015 and updated during the 2019 Biennial. The Charter is composed by 50 principles that are a sort of guidelines for liveable and sustainable public spaces. In order to comprehend the relationship between theory and practice and verify the validity of the Charter after 10 years of its creation, about 30 case studies were collected. The cases are all Italian and quite recent, except two - Piazza del Campo in Siena and Piazza Chanoux in Aosta - which, although hold, are always contemporary in their uses. The general framework which emerges shows different design, planning, cultural, geographical, social and financial factors that can determine the quality of a public space. Starting from these premises, the methodology and main results of this research will be illustrated. Emblematic case studies with particular attention to sustainability will complete the paper.
\end{abstract}

Keywords: urban design, sustainability, public spaces, best practices, urban regeneration.

\section{INTRODUCTION}

Public spaces are places which are designed to be used by the public and realized with public funds. The typology of the public spaces in the last years changed, welcoming new functions, materials, urban furniture, trying to meet the always widening needs of people, including: differentiated lanes for sport, walking and cycling, wireless and QR codes to have information of many kinds, games for all ages and abilities and specific design for the protection by flood and other environmental events [1]-[11]. Nonetheless, the public space does not always give an added value to the area or to an urban regeneration project; accordingly, a Charter of Public Space was carried out and adopted in the framework of the second Biennial of Public Space of Rome [12].

The present research - titled "Public Spaces. From principles to practice" - was carried out by the author in the framework of the "Urban Maestro. New Governance Strategies for Urban Design" Horizon 2020 research project and the INU Community Public Space, the latter coordinated by the author.

The Urban Maestro Project - coordinated by the UCL and in partnership with UN-Habitat "looks at the ways European cities are being designed and financed, focusing on innovative ways of generating and implementing urban spatial quality". Among the objective, the project has the comparison of the experiences in Europe to international practices. Accordingly, the author, as a member of the Advisory and Support Group, shared the good Italian practices in the public space field. 
The Community Public Space of the Italian Institute of Urban Planning (INU) has the objective to collect best practices of public space in Italy, starting from the Charter of Public Space which, as aforementioned, was adopted during the second Biennial of Public Space held in Rome in 2013 and updated during the 2019 Biennial. The Charter is composed by 50 principles that are a sort of guidelines for liveable and sustainable public space. In order to comprehend the relationship between theory and practice and verify the validity of the Charter after 10 years of its creation, about 30 case emblematic studies were collected. The public spaces were chosen in basis on seven categories, including waterfronts, squares, gardens, parks, transportation open-air hubs, nature paths and projects on large scale. The cases are quite recent except two - Piazza del Campo in Siena and Piazza Chanoux in Aosta - which, although hold, are always contemporary in their uses [13].

Starting from this premises, the paper will show in the second section the methodology used for the collection of information. The original method is called QPS-D@taC - Quality Public Space D@ta Collection. Section 3 will report the main principles of the Charter and Section 4 will show four case studies which are particular emblematic with respect to their sustainability achieved in different ways. Finally, Section 5 draws the observation and conclusion. All the case studies are related to one or more principles of the Charter. The general framework which emerges shows different design, planning, cultural, geographical, social and financial factors that can determine the quality of a public space.

\section{THE METHODOLOGY}

The public spaces which were chosen are based on seven categories, including waterfronts, squares, gardens, parks, transportation open-air hubs, nature paths and projects on large scale. The description of the chosen spaces - carried out using the QPS-D@taC - Quality Public Space D@ta Collection method - is realized through a database, constructed collecting the information, images and planimetries useful both in the phase of design and realization of a public space, and in the management phase. Information relative to the success of the space and its presence - where there is - on the social networks are also inserted.

The element 1 to collect is the year of realization. The element 2 is the planimetry or a drawn of the project that make understandable the shape and/or the position of the public space with respect to the surrounding territory.

The element 3 is the city where the space is located and its address. The element 4 is the measure of the surface that covers the area. This data has the function to make comprehending, together with its localization, the "urban weight" of that specific space in the context. It is a physical data but allows to comprehend the wideness of the project intervention.

The element 5 consists in the institutions which are involved. This data is useful to comprehend if and what public entities are involved in the process of realization of the space and if the private sector is involved. The presence of public entities makes clearer the will of the administrations to realize a space that is public and is for the public and, in that case, in what phase of the construction the private sector contributes (namely, in the executive project or in its management). The funds (element 6) is another useful data and is connected to the previous one because it needs to indicate the whole amount, both the public and private ones - where used - of them used to realize the public space. The presence of an urban or urban planning project (element 7) which is the general framework for the realization of the public space makes comprehending both the used planning tool and the wideness of the operation, namely if the public space is part of a greater project of regeneration, or if it is a project which only concerns the public space in object. 
The element 8 consists in the policies which are carried out for the specific public space, but, as the previous data, in the case in which the space has been realized in the framework of a wider project of regeneration, may concerns a wider area.

The element 9 is the kind of uses. This is an information that serves to frame what are the potential activities that are thought for the specific public space and what are those that have been really carried out. This data gives the information also as regards to the success of the project (element 10). The presence of many activities allows the use by people of different ages and then a greater possibility of attendance and satisfaction. The images (element 11) that are collected give the visual illustration of what is described in the database, while the data concerning the factors (element 12) which testify the success of the case study offer a diversified frame of the modality of use, attendance, cultural events and presence on the social networks. In particular, the data concerning the presence on the social networks, although not exhaustive, because the presence of that public space as a background of a picture does not guarantee that the space is agreeable and of success, offers in any case - within a wider framework of information - a news on the typology and quantity of users and on their perception (trough the kind of hashtags, number of followers and likes, or numbers and kinds of comments).

Finally, the database contains the main bibliographical and website references (elements 13-14) and constitute the sources from which information on the public space were collected. This information is collected together with those provided by the technicians and professionals who worked in different way in the realization of the cases in object [13].

\section{THE CHARTER}

The Charter of Public Space aims at serving all those who believe in the city and in its extraordinary ability for hospitality, solidarity, conviviality and sharing; in its inimitable virtue in encouraging social interaction, encounter, togetherness, freedom and democracy; and in its calling for giving life to these values through public space. At the same time, cities show the worsening of economic, social, ethnic, cultural and generational inequalities. Public space must be the place where citizenship rights are guaranteed, and differences are respected and appreciated [12]. In the following, the main principles are reported.

The charter is based on a wide and inclusive concept of citizenship that goes beyond its legal definition. All in their capacity, as users, are "citizens" and have the same rights and duties with regard to the public space.

I. Definition of Public Space

6. Public spaces are all places publicly owned or of public use, accessible and enjoyable by all for free and without a profit motive. Each public space has its own spatial, historic, environmental, social and economic features.

7. Public spaces are a key element of individual and social well-being, the places of a community's collective life, expressions of the diversity of their common natural and cultural richness and a foundation of their identity, as expressed by the European Landscape Convention. The community recognizes itself in its public places and pursues the improvement of their spatial quality.

8. Public spaces consist of open environments (e.g. streets, sidewalks, squares, gardens, parks) and in sheltered spaces created without a profit motive and for everyone's enjoyment (e.g. public libraries, museums). Both when they possess a clear identity, can be defined as "places". The objective is that all public spaces should become "places".

10. Public spaces, whenever safeguards of natural or historical value allow, must be made accessible without barriers to the motorial, sensorially and intellectively handicapped. 
12. Conversely, public spaces which are not yet accessible and/or usable must be considered as "potential public spaces", and therefore as a precious resource for the strengthening and renovation of the existing system of public space, and thus of urban quality as a whole.

II. Typologies of public space

13. Public spaces can be distinguished in: a) spaces that have an exclusive or prevalent functional character; b) spaces that presuppose or favour individual uses; c) spaces that, by mix of functions, form, meanings and by connecting the built with the non-built, have the prevalent role of aggregation and social condensation. In the web of these latter functions is the essence of the city.

14. Public spaces:

a) Are the physical web and support for the movement and the stationing of people and means of transport, from which the vitality of the city depends;

c) Offer precious opportunities for recreation, physical exercise and regeneration for all (parks, gardens, public sports facilities);

f) Promote conviviality, encounter, and freedom of expression;

g) Are an integral and meaningful part of the urban architecture and landscape, with a determinant role in the overall image of the city.

15. For the above characteristics, they represent the principal resource available to public administration on which to build integrated policies and to a broad range of urban planning, of morphological and functional upgrading of the urban fabric and of social and economic regeneration.

III. Creation of public space

16. Every public space should be designed with full consideration for diversity.

18. It is advisable for decisions regarding the creation, the management and the enjoyment of public space to be subjected to clear and transparent participatory processes with all interested stakeholders. Such processes, be they institutionalized, regulated or spontaneous, are to be regarded as a right of urban residents and not as unilateral initiatives of government.

19. It is vital to regard urban public spaces as a continuous, articulated and integrated system, to be developed from the scale of neighbourhoods relationships to vast environmental spaces, to facilitate the diffusion of its enjoyment within the whole community and to raise urban quality.

23. Eliminating and/or overcoming the physical barriers that impede or limit access to certain categories of users is therefore a priority goal to pursue both in the design of new public spaces and in the adaptation of existing ones.

25. Design must pay full attention to maintenance and management costs by using simple solutions and materials that are durable, simple, easily replaceable and climatically adequate.

27. The role of urban public spaces for environmental regulation (drainage, microclimate...), the environmental protection of ecologically valuable areas (river banks, wetlands, biodiversity) and the reduction of urban environmental risks must be taken into account both in the design and management phases.

28. In areas destroyed by catastrophic events public spaces must be the starting point of the reconstruction process.

29. The creation, improvement and management of public spaces can provide an opportunity for new job creation and private investment, also in harmony with the provisions of the European Landscape Convention.

30. Interdisciplinary and participatory approaches to public-space design are an exciting opportunity for planners, landscape professionals, architects, technicians and designers to express fully their social roles. 
VI. Enjoyment of public spaces

43. All citizens, regardless of their role, are users of public space. All of them have the right to access and enjoy it in complete freedom, within the rules of civic coexistence. In cities ever more complex and diverse, this requires democratic processes, dialogue and regard for diversity.

45. The enjoyment of public space involves rights and duties. The right to enjoy adequate public spaces involves the duty to contribute to this goal through freely chosen modalities that can vary from the mere adoption of responsible individual or collective behaviours to involvement in initiatives of active citizenry.

46. The enjoyment of public spaces is a fundamental ingredient for determining and applying indicators of their quality, to be employed throughout the entire creation-management-enjoyment cycle.

48. Events and interventions defined as temporary, included the so-called "urban public art", particularly if linked to an overall strategy, are a form of enjoyment of public space that can become a "good practice" to confer meaning and urban quality to "waiting spaces" rapidly, at low cost and with a strong involvement of the community.

49. The enjoyment of public space is intimately linked to its civil, respectful and responsible use. The quality of public-space enjoyment is therefore tied not only to the availability, quality, mutability, adaptability and maintenance level of public spaces, but also to the behaviour of individual citizens.

50. The good use of public spaces is closely linked to their mutability and adaptability in relation to the changing needs of citizens.

\section{CASE STUDIES}

The research identified emblematic public spaces including waterfronts (such as Matteotti waterfront in Pescara, the Old Port in Genova, the Natural Park on the waterfront in San Benedetto del Tronto, the Foro Italico in Palermo), squares (such as Piazza Matteotti in Catanzaro, Piazza Goldoni in Trieste, Piazza dei Libri in Catania, Piazzetta Mediterraneo, in Palermo, Piazza del Campo in Siena, Piazza Chanoux, in Aosta, Nuova Monteluce, in Perugia, and Corso Nazionale and Piazza Monumento, in Termoli), gardens (such as Sensory garden in Rupicole park in Rome and the Public Garden in San Donà di Piave), parks (such as Parco Portello in Milano, Cavalieri di Vittorio Veneto in Torino, Children Park in Lecce, Music Park in Cagliari), transportation open-air hubs (such as New Civic Centre in Scandicci, Enrico Berlinguer Square, Toledo Station in Napoli and Railway Station in Padova), nature paths (such as RespiArt, Pampeago, in Val di Fiemme, Dosso di San Rocco in Trento, Art-nature path in Val di Sella and Bicycle Lane along the Nera river in Narni) and two project on larger scale (Gardentopia Gardens in Matera and Open Lab Project in Bologna. Of these, the public spaces that are chosen as case studies are: the Waterfront Natural Park in San Benedetto del Tronto, Sensory garden in Rupicole park in Rome, the nature paths of RespiArt, in Val di Fiemme, and the bicycle lane along the Nera river, particularly emblematic for the sustainability [13]-[17].

As regards the Waterfront Natural Park in San Benedetto del Tronto, it is located in the Marche, Central Italy. The park, of about $2,700 \mathrm{~m}^{2}$, was realized in 2007 . The Institution which has involved is the San Benedetto del Tronto Municipality as well as the used funds were municipal. Detailed plan of public initiative for hotel accommodation and related concessions was carried out in order to realize the waterfront.

The main policies which were activated include: the free concession of private spaces for public use, the creation of an urban space for children and the creation of a space with a naturalistic-environmental matrix. 
Many uses have been designed, including walk, run, bicycle, observation and stop. The cycle path that runs along the promenade crosses ten theme gardens and relax areas furnished with seats and both visual and olfactory points of observation. In particular, the Country Garden - with small dunes and an agricultural cart from the Marche region under an arch - reconstructs a typical rural area of the Piceno countryside; the Children's Garden is used for educational games and amusements for children; the Health Garden has medicinal plants which are used for their curative properties; the Citrus Garden, with trees of the Citrus family and a Calamondino, the Mediterranean Garden, with typical essences of the Mediterranean scrub, the palm garden, with 25 species of palms and a bright turf, the Arid Garden with succulents and cacti, the Wet Garden, with a freshwater lake, a bridge and a small waterfall, the Rose Garden, with 27 varieties of roses ("including La Sevillana", which has the characteristic of flourishing several times) have specific aesthetic and ornamental properties and activate the different perceptions. The gardens also serve as access to the bathing establishments and at various times of the year cultural and social events are there organized.

The fruition is of different types. The thematic gardens are all equipped with information guides, tactile maps and plates for each species of plants, which support its didactic function, and are also usable by the blind.

The elements that testify the success of the public space include: the insertion in the network of blogs for opinions on the gardens of the Marche region; the Organization of periodic visits to the theme gardens during the summer period; and the organization of events of different kinds during the year. As a further element that testify the success of this space, although there is no presence of it in the social networks, many web sites contain information about this waterfront and its activities.

Among the gardens, the Sensory garden at the Rupicole Park in Rome is particular interesting. The garden was realized in 2012 in a surface of $4,000 \mathrm{~m}^{2}$. The property is public and the Institution that is involved in the creation of the space is "Roma Capitale" - Department of Social Services and Health Promotion. The Institutions involved in the management of the garden include: the Department of Social Policies of the Municipality of Rome and the Botanical Garden of Tor Vergata with some researchers and teachers, who carried out activities with the disabled (gardening courses and more); Cospexa social cooperative: Project 96, the Center for Social Integration, Obiettivo Uomo, Iskra, Virtus Italia and the Istituto Sant'Antonio.

The funds for the construction of the space are also public and were given by the Lazio Region - Rome Capital Program, and the funds for the management were given by the Municipality of Rome, Botanical Garden.

The urban planning tool of reference is the 2008 General Regulatory Plan (Italian acronym PRG) Public green and local public services, while the urban project was carried out by the Botanical garden in collaboration with a private studio of architecture (mtstudio). The urban policies and types of use are many. The garden is used two days a week by a nearby association of disabled. Gardening courses are organized, and participants can obtain a certificate. In this way, the garden is kept in order through the courses, without great expenses for the public administration. The goal is to create a space for all residents of the neighbourhood, where recreational activities, socialization, job placement and rehabilitation can also be carried out, such as gardening training courses for people with different forms of disabilities. Other uses include: workshops in green areas for children, teenagers and disabled adults; horticultural therapy and aromatherapy; the management and arrangement of the garden by guests of the accommodation community; integration between the guests of 
the housing community, the residents of the neighbourhood (children, adults and the elderly) and the institutions of the area.

As regards the fruition, the garden is fully usable from all points of view. There is also a particular sensorial path, which, thanks to the help of a handrail and tactile paving for the blind, allows easy access for the visually impaired.

The parking areas, located along the routes, are of great importance for the elderly, as well as for the people with motor and sensory disability.

With respect to the elements that testify the success of the case study, for the first time, an interaction has taken place between the various social cooperatives that have taken part in the activities planned on the proposal of Cospexa. The Horticultural therapy is a rehabilitative method for discomfort and disability. It consists of encouraging, preparing and supporting the subject in the care and management of greenery, in the cultivation of flowers, vegetables and other plants.

The project includes an age group between 20 and 50 years old, between mentally and physically disabled people, who have attitudes for this type of work. The maximum number of patients is 50. The public administration of Rome was also awarded, and the project won the "Simonetta Bastelli" award in 2013.

As regards the social media, the garden is present on twitter with 703 likes and on Facebook with 2,463 likes.

With respect to the nature path, RespiArt, Pampeago in Val di Fiemme (Sudtirol) was carried out in 2011 in a $3 \mathrm{~km}$ route. The property consists of a small public part (the Municipality of Tesero) and in a large private part (the Magnifica Comunità di Fiemme). The project born from a project by the journalist and art curator Beatrice Calamari and the artist Marco Nones. The institutions involved in the project management include Val di Fiemme Tourism Board and Trentino Marketing which help to promote the park. The historic body of the "Magnifica Comunità di Fiemme" (which has managed the forests of the Val di Fiemme since 1111) donates wood for the creation of the works, and the hotels in the Val di Fiemme host the artists. The funds for the construction and the management of the space are constituted by private contributions. The urban planning tools of reference is constituted by the 2010 variant to the General Regulatory Plan of the Municipality of Tesero and other plans for specific areas including the high integrity area E108, the pasture areas E107, and the skiable areas and ski lift systems, D208.

The policies which were activated consist in the concession of spaces for cultural and social events. RespirArt invites visitors to relax in the ever-changing nature, allowing to rediscover the sense of wonder, taking the new as an unrepeatable opportunity. Atmospheric agents do not damage the works, but complete them, shaping them and changing their colours.

The uses concern the walk and the stop, as well as guided visits to discover nature, art and typical food, and wine products. Outdoor concerts are held in the park at the Latemar theatre, which organizes a large theatrical season. Among the elements that testify the success of the space, RespirArt collaborates assiduously with Italian and foreign artists and cultural associations. The new projects mean that the park becomes not only an artistic, but also a social and cultural centre of reference, such as the case of the "RespirArt Day", an itinerant party with artists, which has reached the tenth edition.

The entrance to the RespirArt park is completely free. During the winter, the park can only be visited with skis, as it is crossed by the Agnello slope of the Ski Centre Latemar. Being a high-altitude park in the Unesco Dolomites, it has not been violated by asphalting, earth movements or other impactful interventions. It runs on mountain paths with small, slightly steep sections. Therefore, it is not possible to access with wheelchairs. 
As regards the social networks, the park is present on Instagram with 917 followers and 1,389 likes, Facebook with 1,124 followers and 1,118 likes, and on YouTube there is a presentation video on the Visitfiemme channel.

The last case study of public space is the Bike path along the Nera river and the greenways of the Nera gorges which was realized in 2016 in Narni, in a surface of $11 \mathrm{~km}$.

The Institution which was involved is the Municipality of Narni and the funds come from the "Cycle path along the Nera river" (Narni - Nera Montoro - Oasis of San Liberato) - POR FESR 2007-2013 - AXIS II - Activity b2, and the Project for the enhancement of the banks of the Nera and the greenways of the Nera gorges - POR FESR 2007-2013 - AXIS II - Activity b1.

As regards the urban project, Narni municipal administration implemented the program. The interventions that led to the creation of the Greenways along the Gorges of the Black River were designed by a team of various professionals.

The policies which were carried out are many. The intervention is configured within a complex program of enhancement of the gorges of the Nera river, aimed at: activating an economic process of sustainable development and requalification of the environmental landscape heritage; consolidating a territorial offer qualified in cultural and environmental terms; and stimulating local development and its insertion in the large regional tourist circuits. The goal was to develop a strategic line for the creation of greenways routes and demonstrate how these can be a tool for enhancing the territory and its resources and representing a potential means for alternative mobility for daily movements, recreational activities and tourism.

With respect to the type of use, the project is based on the environmental redevelopment of the area of the Nera River, where the infrastructures and services are concentrated, and runs longitudinally, taking advantage of the waterway and the complex system of paths that develop along the two sides. Along this system, significant polarities are articulated in settlement terms. Furthermore, along the slopes, a series of specific elements of attraction lead the visitor to areas and artefacts of historical, archaeological and landscape interest, villages, abbeys, natural sources, ancient industrial settlements. The park consists of an integrated system of spaces, places of community life and its collective memory and paths for cycle and pedestrian mobility capable of responding to the growing demand for meeting and non-systematic mobility, including tourism and hospitality. It is a space that, promoting the meeting and conviviality as well as offering opportunities for recreation and exercise, has a prevalent role of social aggregation.

Among the elements that testify the success of the path, in 2017 there was a presence of up to 500-600 people passing through. With the creation of a Temporary Purpose Association (which deals with animation, provision of services, ordinary maintenance and promotion of the tourist itineraries of the Gorges with the spirit of enhancing the cultural, food and wine, music and sports activities of the area) which manages this area, a further increasing in visitors and passing people is expected. With respect to the social network, Gole Del Nera is on Facebook with 3,071 followers and on Instagram with 1,001 followers.

\section{OBSERVATION AND CONCLUSION}

The paper has illustrated a research carried out in the framework of the Urban Maestro Horizon 2020 project and the INU Community Public Space. The research has as an object to collect best practices of public space in Italy, starting from the Charter of Public Space which was adopted during the second Biennial of Public Space, held in Rome in 2013, and updated during the 2019 Biennial and, contemporaneously, to verify its current validity. 
The method which was used for the case studies is the QPS-D@taC - Quality Public Space D@ta Collection one. The general framework which emerged shows different design, planning, cultural, geographical, social and financial factors that can determine the quality and sustainability of a public space.

The cases concern waterfronts (in Pescara, Genova, San Benedetto del Tronto and Palermo), squares (in Catanzaro, Trieste, Catania, Palermo, Siena, Aosta, Perugia, and Termoli), gardens (in Rome and San Donà di Piave), parks (in Milano, Torino, Lecce, Cagliari, transportation open-air hubs (in Scandicci, Napoli and Padova), nature paths (in Trento, Val di Sella and Nera river) and projects on larger scale (in Matera and in Bologna. Of these, the public spaces that are chosen as case studies include: the Waterfront Natural Park in San Benedetto del Tronto, the Sensory garden in Rupicole park in Rome, the nature paths of RespiArt, in Val di Fiemme, and the Bicycle lane along the Nera river.

The case studies which were chosen for this paper are particularly focused on the social, economic and environmental sustainability. Furthermore, in all the public spaces, many of the principle of the Charter of Public Space are followed. In particular, the first - namely "Public spaces are all places publicly owned or of public use, accessible and enjoyable by all for free and without a profit motive. Each public space has its own spatial, historic, environmental, social and economic features" $-13,14$ and 15 are always followed.

The aims of the study are in this way carried out. In the first case, that of the Natural Park on the Waterfront in San Benedetto del Tronto, the main policies and uses include: the free concession of private spaces for public use; the creation of an urban space for children and the creation of a space with a naturalistic-environmental matrix; the garden to be used for educational games and amusements for children; and the Health Garden with medicinal plants. The Park is easily accessible and is used in all the seasons representing an important place of socialization and its social, economic and environmental sustainability.

In the second case, the Sensory garden at the Rupicole Park in Rome, spaces for all residents of the neighbourhood are carried out, with recreational activities, socialization, job placement and rehabilitation, such as gardening training courses for people with different forms of disabilities, workshops in green areas for children, teenagers and disabled adults; horticultural therapy and aromatherapy; the management and arrangement of the garden by guests of the accommodation community; integration between the guests of the housing community, the residents of the neighbourhood (children, adults and the elderly) and the institutions in the area. The workshop has also the function to contribute to the management of the garden with a small contribute by the Administration. Also in this space, the sustainability in its threefold meaning is respected.

As regards the nature path, RespiArt, Pampeago in Val di Fiemme, the policies which were activated consist in the concession of spaces for cultural and social events while the uses concern the walk and the stop, as well as guided visits to discover nature, art and typical food and wine products. Being a high-altitude park in the Unesco Dolomites, it has not been violated by asphalting, earth movements or other impactful interventions.

The last case was the Cycle path along the Nera river which promoted policies to activate an economic process of sustainable development and requalification of the environmental landscape heritage in order to consolidate a territorial offer qualified in cultural and environmental terms and to stimulate local development and its insertion in the large regional tourist circuits. Also, these two last case studies are projects which take in particular account the sustainability.

The public spaces are mainly realized with public funds, in the framework of wider urban planning tools, and have all activated urban policies that allow an overall and sustainable success. 
Finally, the research has now a new goal. Due to the current pandemic event, public spaces were not used for months. Indeed, a new challenge is occurring for the sanitary emergency [18], requiring - as a future step of the study - an update of the methodology and case studies. The flexibility of the method which was used for the collection of the data allows that some factors can be added to the database aimed at verifying how the social and physical distance will be carried out in the public spaces and how, for effect of this distance, the use of the places will change. Furthermore, new data to collect could arise from the updated onsite inspections, including new ways to use the spaces and new equipment and urban furniture which will probably change movements, paces and fruitions.

\section{REFERENCES}

[1] Appleyard, D., Liveable Streets, University of California Press: Berkeley, 1981.

[2] Gehl, J., Cities For people, Island Press: Washington, 2010.

[3] Friedmann, J., Place and place-making in cities: A global perspective. Planning Theory \& Practice, 11(2), pp. 149-165, 2010.

[4] Kent, F., Street as Place. Using Streets to Rebuild Communities, Project for public spaces: New York, 2008.

[5] Carmona, M., Heath, T., Oc, T. \& Tiesdell, S., Public places-Urban spaces, Architectural Press: Oxford, 2010.

[6] Gospodini, A., Culture-led regeneration in European cities: The question of sustainability and critical parameters of culture and leisure epicentres. dis $P$ - The Planning Review, 53(2), pp. 66-67, 2017.

[7] Montgomery, J., Making a city: Urbanity, vitality and urban design. Journal of Urban Design, 3, pp. 93-116, 1998.

[8] Zelinka, A. \& Brennan, D., Safescape, Creating Safer, More Livable Communities Though Planning and Design, Planner Press APA: Chicago, 2001.

[9] Madanipour, A., Public and Private Spaces of the City, Routledge: London, 2003.

[10] Satta, C. \& Scandurra, G., Sport and public space in contemporary Italian cities: Processes of citizenship construction through body-related practices. Modern Italy, 20(3), pp. 229-236, 2015.

[11] Francis, J., Giles-Corti, B., Wood, L. \& Knuiman, M., Creating sense of community: The role of public space. Journal of Environmental Psychology, 32, pp. 401-409, 2012.

[12] Garau P., Lancerin L. \& Sepe M., The Charter of Public Space, LiST: Trento, 2015.

[13] Sepe, M., Spazi pubblici nella città contemporanea, Inu Edizioni: Roma, 2020.

[14] Sepe, M., Planning and Place in the City. Mapping Place Identity, Routledge: London and New York, 2013.

[15] Sepe, M., Regenerating places sustainably: The healthy urban design. International Journal of Sustainable Development and Planning, 15(1), pp. 14-27, 2020.

[16] Sepe, M., Placemaking, livability and public spaces: Achieving sustainability through happy places. Journal of Public Space, 2(4), pp. 63-76, 2017.

[17] Sepe, M., Places and perceptions in contemporary city. Urban Design International, 18(2), pp. 111-113, 2013.

[18] Opdam, P., Implementing human health as a landscape service in collaborative landscape approaches. Landscape and Urban Planning, 199, 2020. 